\title{
USING OF RESPONSE SURFACE METHODOLOGY FOR OPTIMIZATION OF BIOHYDROGEN PRODUCTION BY CLOSTRIDIUM SP. TR2 ISOLATED IN VIETNAM
}

\author{
Nguyen Thi Thu Huyen*, Dang Thi Yen, Nguyen Thi Yen, \\ Vuong Thi Nga, Lai Thuy Hien
}

Institute of Biotechnology, VAST, "huyen308@gmail.com

\begin{abstract}
Biohydrogen is a clean, renewable, sustainable energy resource due to the highest energy density among all fuels and its combustion has no contribution to the environmental pollution and climate change. Biohydrogen production depends on a number of nutritional and environmental variables. The present paper is to determine the optimum condition for enhanced hydrogen production by a fermentative hydrogen-producing bacterium (designated as Clostridium sp. Tr2) isolated from buffalo-dung in Vietnam. The response surface methodology (RSM) was employed to determine the mutual effects of glucose, yeast extract and iron concentration on its hydrogen production in a batch condition. RSM analysis showed that the highest hydrogen production potential (Ps) was obtained under the condition of $10.18 \mathrm{~g} \mathrm{~L}^{-1}$ glucose, $2.5 \mathrm{~g} \mathrm{~L}^{-1}$ yeast extract and $58 \mathrm{mg} \mathrm{L}^{-1} \mathrm{FeSO}_{4} .7 \mathrm{H}_{2} \mathrm{O}$. All three factors had significant influences on the Ps. Glucose and iron concentration, yeast extract and iron concentration were interdependent or there was a significant interaction on Ps. Glucose and yeast extract concentration was slightly interdependent, or their interactive effect on Ps was not significant. Under optimum conditions, the maximum $\mathrm{H}_{2}$ volume of $1080 \mathrm{ml}$ (L medium $)^{-1}$ were found after $22 \mathrm{~h}$ facultative anaerobic fermentation. The experiment results show that the RSM analysis with the central composite design was useful for optimizing the biohydrogen-producing process by newly isolated Clostridium sp. Tr2 in Vietnam.
\end{abstract}

Keywords: Clostridium, bacteria, biohydrogen, fermentation, optimization, RSM, Vietnam.

\section{INTRODUCTION}

Fermentative hydrogen production is a very complex process and is greatly influenced by many factors, such as substrate, nitrogen, metal ion, temperature and $\mathrm{pH}[1,10,3,4,5]$. The optimization of fermentation conditions, particularly nutritional and environmental parameters are very important. There are two ways by which the problem of fermentation parameters may be addressed: classical (singlefactor design) and statistical (multiple-factor design). In comparison with the classical methods, the statistical methods are believed to be more effective and powerful in screening key factors from a multi-variable system and optimizing fermentation conditions. They are also more time-saving and error-proof in determining the effect of parameters [10,7]. Some statistical methods, such as response surface methodology (RSM) with various designs have been successfully employed for biohydrogen production optimization $[8,2,6]$.

In the previous study, we applied the classical method (single-factor design) to find out the effect of single nutritional and environmental factors on hydrogen production of a hydrogen-producing fermentative bacterium (designated as Clostridium sp Tr2) isolated from buffalo-dung in Vietnam. In the present study, we used response surface methodology (RSM) to investigate the mutual effect of glucose, yeast extract, and iron concentration to more improve hydrogen production using the pure Clostridium sp. $\operatorname{Tr} 2$.

\section{MATERIALS AND METHODS}

\section{Strain and medium}

Clostridium sp. Tr2 isolated from buffalodung in Vietnam was used. The basic medium used for enrichment and cultivation of $\mathrm{H}_{2}$ producing strain $\operatorname{Tr} 2$ in this study is NMV (nutrient mineral vitamin) medium. NMV contains glucose $5 \mathrm{~g} \mathrm{~L}-1$, meat extract $1 \mathrm{~g} \mathrm{~L}-1$, yeast extract $3 \mathrm{~g} \mathrm{~L}-1$, peptone $1 \mathrm{~g} \mathrm{~L}-1$, , NH4Cl $1 \mathrm{~g} \mathrm{~L}-1, \mathrm{KH} 2 \mathrm{PO} 40.5 \mathrm{~g} \mathrm{~L}-1, \mathrm{~K} 2 \mathrm{HPO} 40.5 \mathrm{~g} \mathrm{~L}-$ 1, $\mathrm{KCl} 0.1 \mathrm{~g} \mathrm{~L}-1, \mathrm{NaCl} 1 \mathrm{~g} \mathrm{~L}-1, \mathrm{CaCl} 20.1 \mathrm{~g} \mathrm{~L}-$ 1, MgSO4.7H2O 0.3 g L-1, FeSO4.7H2O $0.1 \mathrm{~g}$ L-1, L-cysteine HCl.H2O 0.5 g L-1, mineral 
solution $1 \mathrm{ml} \mathrm{L}-1$, vitamin solution $1 \mathrm{ml} \mathrm{L}-1$, vitamin C (100 ml mL-1) $0.5 \mathrm{ml} \mathrm{L}-1$, resazurin $(0.2 \%) 1 \mathrm{ml} \mathrm{L}-1 . \mathrm{pH}$ is adjusted to 6.5. Agar 15 $\mathrm{g} \mathrm{L}-1$ is added for solid medium. Mineral solution consists of $\mathrm{MnSO} 4.7 \mathrm{H} 2 \mathrm{O} 1 \mathrm{~g} \mathrm{~L}-1$, $\mathrm{ZnSO} 4.7 \mathrm{H} 2 \mathrm{O} 5 \mathrm{~g}$ L-1, $\mathrm{H} 3 \mathrm{BO} 31 \mathrm{~g}$ L-1, $\mathrm{CaCl} 2.2 \mathrm{H} 2 \mathrm{O} 1 \mathrm{~g} \mathrm{~L}-1, \mathrm{NiSO} 41.6 \mathrm{~g} \mathrm{~L}-1$, $\mathrm{CuCl} 2.2 \mathrm{H} 2 \mathrm{O} 1.5 \mathrm{~g} \mathrm{~L}-1$, EDTA $1 \mathrm{~g} \mathrm{~L}-1$. The chemicals of vitamin solution are cyanocobalamin $1 \mathrm{~g} \mathrm{~L}-1$, riboflavin $2.5 \mathrm{~g} \mathrm{~L}-1$, sodium citrate $2 \mathrm{~g} \mathrm{~L}-1$, pyridoxine $0.5 \mathrm{~g} \mathrm{~L}-1$, folic acid $1 \mathrm{~g} \mathrm{~L}-1$, 4-aminobenzoic acid $1 \mathrm{~g} \mathrm{~L}-1$.

\section{Cultivation}

For RSM study: All experiments were performed in $120 \mathrm{ml}$ serum bottles as batch reactors, which contained $100 \mathrm{ml}$ of medium and $10 \%$ inoculum $(\mathrm{v} / \mathrm{v})$ that was harvested after $16 \mathrm{~h}$ of pre-cultivation under facultative anaerobic condition at $30^{\circ} \mathrm{C}$. Glucose, yeast extract, iron concentration of media were changed according to the experimental design (table 1). Twenty trials were run to evaluate the effects of glucose, yeast extract, iron concentration on hydrogen production. Hydrogen production potential was estimated basing on the total gas volume measuring by water displacement method.

For batch fermentor set-up: Experiment was performed $600 \mathrm{ml}$ serum bottles with $500 \mathrm{ml}$ medium under facultative anaerobic fermentation at $30^{\circ} \mathrm{C}$. Glucose, yeast extract, iron concentration of media were added basing on RSM results. Ten percent (v/v) overnight grown seed culture after $16 \mathrm{~h}$ of pre-cultivation was used as inoculum. The evolved gas mixture was collected in a gas collector by displacement of saturated $\mathrm{NaCl}$ solution at normal temperature and atmospheric pressure. The batch experiment was continued until hydrogen production ceased.

\section{Analytical methods}

The amount of biogas produced was recorded by using water-displacement method with saturated $\mathrm{NaCl}$ solution.

The gas products (mainly $\mathrm{H}_{2}$ and a little of $\mathrm{CO}_{2}$ and $\mathrm{H}_{2} \mathrm{~S}$ ) was analyzed by gas chromatography GC-TCD (Thermo Trace GCThermo Electro-USA) with a thermal conductivity detector.

\section{Statistical analysis}

RSM with a full factorial central composite design (CCD) was employed in this study, as shown in table 1 . The variables were coded according to the following equation:

$$
x_{i}=\frac{X_{i}-X_{i}^{*}}{\Delta X_{i}}
$$

Where, $x_{i}$ is the coded value of the $i^{\text {th }}$ test variable; $X_{i}$ is the uncoded value of the $i^{\text {th }}$ test variable, $X_{i}^{*}$ is the value of $X_{i}$ at the centre point of the investigated area, and $\Delta \mathrm{X}_{\mathrm{i}}$ is the step size. Glucose concentration (X1), yeast extract concentration (X2) and iron concentration (X3) were chosen as three independent factors in the experimental design. The central values of experiment design were selected as glucose concentration $10.0 \mathrm{~g} \mathrm{~L}^{-1}$, yeast extract concentration $3.0 \mathrm{~g} \mathrm{~L}^{-1}$ and $\mathrm{FeSO}_{4} .7 \mathrm{H}_{2} \mathrm{O}$ concentration $100 \mathrm{mg} \mathrm{L}^{-1}$, which were as close as possible to the optimum values based on our previous study (unpublished data). Design-Expert software 7.1 (Stat-Ease, Inc., Minneapolis, USA) was used for data analysis.

Table 1. A 20 full factorial CCD with six replicates of the centre point for $\mathrm{H}_{2}$ production potential

\begin{tabular}{|c|c|c|c|c|c|c|c|}
\hline \multirow{3}{*}{ Trial } & \multicolumn{2}{|c|}{$\begin{array}{c}\text { Glucose } \\
\left(\mathrm{A}=\mathrm{X}_{1}\right)\left(\mathrm{g} \mathrm{L}^{-1}\right)\end{array}$} & \multicolumn{2}{c|}{$\begin{array}{c}\text { Yeast extract } \\
\left(\mathrm{B}=\mathrm{X}_{2}\right)\left(\mathrm{g} \mathrm{L}^{-1}\right)\end{array}$} & \multicolumn{2}{c|}{$\begin{array}{c}\text { FeSO4.7H2O } \\
\left(\mathrm{C}=\mathrm{X}_{3}\right)\left(\mathrm{mg} \mathrm{L}^{-1}\right)\end{array}$} & $\begin{array}{c}\text { Ps, Y } \\
(\mathrm{ml} / 100 \\
\end{array}$ \\
\cline { 2 - 8 } & $\begin{array}{c}\text { Real } \\
\text { value }\end{array}$ & $\begin{array}{c}\text { Code } \\
\text { value }\end{array}$ & $\begin{array}{c}\text { Real } \\
\text { value }\end{array}$ & $\begin{array}{c}\text { Code } \\
\text { value }\end{array}$ & $\begin{array}{c}\text { Real } \\
\text { value }\end{array}$ & $\begin{array}{c}\text { Code } \\
\text { value }\end{array}$ & $\begin{array}{c}\text { ml } \\
\text { medium })\end{array}$ \\
\hline 1 & 10 & 0 & 4.68 & +1 & 100 & 0 & 100 \\
\hline 2 & 10 & 0 & 3 & 0 & 100 & 0 & 102 \\
\hline 3 & 10 & 0 & 3 & 0 & 184.09 & +1 & 80 \\
\hline 4 & 8 & -1 & 2 & -1 & 50 & -1 & 56.11 \\
\hline 5 & 8 & -1 & 2 & -1 & 150 & +1 & 79.64 \\
\hline 6 & 10 & 0 & 3 & 0 & 100 & 0 & 102.5 \\
\hline
\end{tabular}




\begin{tabular}{|c|c|c|c|c|c|c|c|}
\hline 7 & 10 & 0 & 3 & 0 & 15.91 & -1 & 60 \\
\hline 8 & 10 & 0 & 1.31 & -1 & 100 & 0 & 70 \\
\hline 9 & 10 & 0 & 3 & 0 & 100 & 0 & 102.5 \\
\hline 10 & 8 & -1 & 4 & +1 & 50 & -1 & 74.52 \\
\hline 11 & 12 & +1 & 4 & +1 & 150 & +1 & 94 \\
\hline 12 & 12 & +1 & 4 & +1 & 50 & -1 & 94.21 \\
\hline 13 & 10 & 0 & 3 & 0 & 100 & 0 & 102.5 \\
\hline 14 & 10 & 0 & 3 & 0 & 100 & 0 & 102.5 \\
\hline 15 & 6.64 & -1 & 3 & 0 & 100 & 0 & 85 \\
\hline 16 & 13.36 & +1 & 3 & 0 & 100 & 0 & 100 \\
\hline 17 & 12 & +1 & 2 & -1 & 50 & -1 & 76.5 \\
\hline 18 & 8 & -1 & 4 & +1 & 150 & +1 & 97 \\
\hline 19 & 10 & 0 & 3 & 0 & 100 & 0 & 102.5 \\
\hline 20 & 12 & +1 & 2 & -1 & 150 & +1 & 77.21 \\
\hline
\end{tabular}

\section{RESULTS AND DISCUSSION}

In previous study, we examined the effect of each factor on biohydrogen production of strain Clostridium sp. Tr2 by classical method (single-factor design) (unpublished data). It pointed out that concentration of glucose, yeast extract and iron very strong impacted on hydrogen production of strain $\operatorname{Tr} 2$. However, the values depended on the "onevariable-at-a-time" approach couldn't explain the mutual interactions between the independent variables. Thus, in this study, the interactive effects of these three factors selected as key parameters were investigated for further optimization to maximize the hydrogen production of strain Tr2 by RSM approach basing on our single-factor design optimization results.

RSM with CCD was applied to optimize the variables of the key factors (glucose, yeast extract, $\mathrm{FeSO}_{4} \cdot 7 \mathrm{H}_{2} \mathrm{O}$ concentration) and the effect of their interactions on hydrogen production with the purpose of obtaining the highest hydrogen yield during the fermentation process. Based on the CCD analysis, the experimental design and results are displayed in table 1. The response of the center point (glucose $=10 \mathrm{~g} \mathrm{~L}^{-1}$, yeast extract $=3 \mathrm{~g} \mathrm{~L}^{-1}$, FeSO4.7H2O $=100 \mathrm{mg} \mathrm{L}^{-1}$ ) was $102.5 \mathrm{ml} \mathrm{H}_{2}$ $(100 \mathrm{ml} \mathrm{medium})^{-1}$. The regression equation obtained after the analysis of variance gave the level of response as a function of three independent variables. The final model was obtained by multiple regression analysis of the experimental data and expressed by the following equation:

$\mathrm{Y}=-208.566+25.80041 \mathrm{~A}+47.25356 \mathrm{~B}+$ $1.620319 \mathrm{C}-0.07938 \mathrm{AB}-0.05689 \mathrm{AC}-0.00492 \mathrm{BC}-$ $0.88407 \mathrm{~A}^{2}-6.18792 \mathrm{~B}^{2}-0.0046 \mathrm{C}^{2}$

Where, $\mathrm{Y}$ is the predicted hydrogen production potential (ml hydro/100 $\mathrm{ml}$ medium); $\mathrm{A}, \mathrm{B}$ and $\mathrm{C}$ are the coded values of glucose, yeast extract and $\mathrm{FeSO}_{4} \cdot 7 \mathrm{H}_{2} \mathrm{O}$ concentration, respectively.

Table 2. ANOVA for the hydrogen production potential

\begin{tabular}{|l|c|c|c|c|c|c|}
\hline \multirow{2}{*}{ Factors } & \multicolumn{7}{c|}{ Statistics } \\
\cline { 2 - 8 } & $\begin{array}{c}\text { Sum of } \\
\text { Squares }\end{array}$ & $\begin{array}{c}\text { Degree of } \\
\text { freedom }\end{array}$ & $\begin{array}{c}\text { Mean } \\
\text { Square }\end{array}$ & $F$-value & $\begin{array}{c}p \text {-value } \\
\text { Prob }>\mathrm{F}\end{array}$ & \\
\hline Model & 4388.525 & 9 & 487.6139 & 10859.36 & $<0.0001$ & significant \\
\hline A-glucose & 262.5233 & 1 & 262.5233 & 5846.502 & $<0.0001$ & \\
\hline B-yeast extract & 1067.173 & 1 & 1067.173 & 23766.39 & $<0.0001$ & \\
\hline C-FeSO4.7H2O & 470.3395 & 1 & 470.3395 & 10474.66 & $<0.0001$ & \\
\hline AB & 0.201613 & 1 & 0.201613 & 4.489994 & 0.0601 & \\
\hline
\end{tabular}


Nguyen Thi Thu Huyen et al.

\begin{tabular}{|l|r|c|r|r|l|l|}
\hline $\mathrm{AC}$ & 258.895 & 1 & 258.895 & 5765.699 & $<0.0001$ & \\
\hline $\mathrm{BC}$ & 0.485113 & 1 & 0.485113 & 10.80366 & 0.0082 & \\
\hline $\mathrm{A}^{2}$ & 180.216 & 1 & 180.216 & 4013.486 & $<0.0001$ & \\
\hline $\mathrm{B}^{2}$ & 551.8133 & 1 & 551.8133 & 12289.11 & $<0.0001$ & \\
\hline $\mathrm{C}^{2}$ & 1902.984 & 1 & 1902.984 & 42380.24 & $<0.0001$ & \\
\hline Residual & 0.449026 & 10 & 0.044903 & & & \\
\hline Lack of Fit & 0.240693 & 5 & 0.048139 & 1.155326 & 0.4390 & $\begin{array}{l}\text { not } \\
\text { significant }\end{array}$ \\
\hline Pure Error & 0.208333 & 5 & 0.041667 & & & \\
\hline Cor Total & 4388.974 & 19 & & & & \\
\hline & \multicolumn{7}{|l|}{$\mathrm{R}^{2}=0.999898 \mathrm{R} 2(\mathrm{Adj})=0.999806 \mathrm{R} 2($ Pred $)=0.999515$} \\
\hline
\end{tabular}

To validate the statistical results and the model equation, an analysis of variance (ANOVA) was conducted and the results are shown in table 2. The model F-value of 10859.36 and values of "Prob > F" less than 0.05 implied significant model fit. The "Lack of Fit F-value" of 1.16 implies the Lack of Fit is not significant relative to the pure error. There is a $43.90 \%$ chance that a "Lack of Fit F-value" this large could occur due to noise. Thus, the lack of fit is insignificant. It meant the model was good. The high value of regression coefficient $(\mathrm{R}=0.999)$ and the "Pred R-Squared" of 0.9995 is in reasonable agreement with the "Adj R-Squared" of 0.9998 . These suggested that the regression model was an accurate representation of the experimental data. Furthermore, "adequate precision" measures the signal to noise ratio. A ratio greater than 4 is desirable; a ratio of 309.681 indicated an adequate signal, which meant the model could be used to navigate the design space. These findings indicated that the model equation obtained was statistical for predicting the effects of glucose, yeast extract, and iron concentration on hydrogen production potential. It can also be seen from table 2 that the linear and quadratic effects of glucose, yeast extract and iron concentration, as well as the interactive effect between glucose and iron concentration, and yeast extract and iron concentration were highly significant $(\mathrm{P}<0.05)$, while the interactive effect between glucose and yeast extract concentration was not so significant $(\mathrm{P}>0.05)$.

The optimum level of each variable and the effect of their interactions on the hydrogen production were studied by plotting threedimensional response surfaces (Fig. 1). The figures are based on equation (1) with one variable kept constant at its optimum level and varying the other two variables within the experimental range. The three-dimensional curves of the calculated responses show the interactions between glucose and yeast extract concentration, glucose and $\mathrm{FeSO}_{4} .7 \mathrm{H}_{2} \mathrm{O}$ concentration, yeast extract and $\mathrm{FeSO}_{4} .7 \mathrm{H}_{2} \mathrm{O}$ concentration in Fig. 1a-c, respectively. By analyzing the plots (Fig. 1), initial substrate concentration and $\mathrm{Fe}^{2+}$ were found to play important roles on the hydrogen production as indicated in other studies $[2,6]$. In addition, yeast extract had also effect on hydrogen production that was contrary to report of Long et al. (2010) [6] in which the organic nitrogen source (peptone) had no effects on hydrogen production.

To further validate optimal values, the optimal values of the variables affected the yield of the hydrogen production given by the software which calculated the equation giving the following results: $\mathrm{A}=10.18 ; \mathrm{B}=2.5 ; \mathrm{C}=$ 58. Therefore, the optimal values of the variables combination were the following: glucose was $10.18 \mathrm{~g} \mathrm{~L}^{-1}$, yeast extract was $2.5 \mathrm{~g}$ $\mathrm{L}^{-1}$, and $\mathrm{FeSO}_{4} .7 \mathrm{H}_{2} \mathrm{O}$ was $58 \mathrm{mg} \mathrm{L}^{-1}$. The maximum predicted value of Ps was $1080 \mathrm{ml} \mathrm{H}_{2}$ $(\mathrm{L} \text { medium })^{-1}$. According to the results of the statistically designed experiments, the flaskscale fermentation was performed under this optimal concentration. After $22 \mathrm{~h}$ of fermentation, the maximum production of hydrogen was estimated as $540 \mathrm{ml} \mathrm{H} \mathrm{H}_{2}(500 \mathrm{ml}$ 
medium $)^{-1}$, more than our previous optimization result by "one-variable-at-a-time" method $(510$ $\mathrm{ml} \mathrm{H}_{2} / 500 \mathrm{ml}$ medium) (unpublished data). Therefore, the response surface optimization could be successfully used to evaluate the biohydrogen production performance and to achieve higher yield of biohydrogen production in this study.
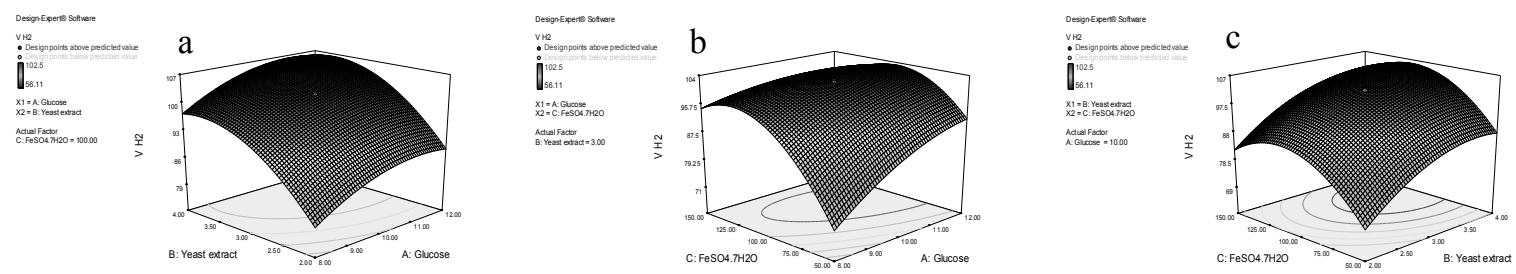

Fig. 1. Three-dimensional response plots showing interaction effects on the response $\mathrm{Ps}\left(\mathrm{ml} \mathrm{H}_{2} / 100 \mathrm{ml}\right.$ medium)

a. The effects of glucose $\left(\mathrm{g} \mathrm{L}^{-1}\right)(\mathrm{A})$ and yeast extract $\left(\mathrm{g} \mathrm{L}^{-}\right)(\mathrm{B}) ; \mathrm{b}$. The effects of glucose $\left(\mathrm{g} \mathrm{L}^{-}\right)(\mathrm{A})$ and $\mathrm{FeSO}_{4} .7 \mathrm{H} 2 \mathrm{O}\left(\mathrm{mg} \mathrm{L}^{-}\right)(\mathrm{C})$; c. The effects of yeast extract $\left(\mathrm{g} \mathrm{L}^{-}\right)(\mathrm{B})$ and $\mathrm{FeSO}_{4} 7 \mathrm{H} 20\left(\mathrm{mg} \mathrm{L}^{-}\right)(\mathrm{C})$.

\section{CONCLUSION}

The present work focused on the optimization of key parameters for improving the biohydrogen production using the statistical methodology. Experimental results showed that glucose, yeast extract and iron concentration all had significant influences on the hydrogen production potential. Glucose and iron concentration, yeast extract and iron concentration were interdependent and had a significant interactive effect on the hydrogen production potential. On the other hand, glucose and yeast extract concentration was slightly interdependent, and their interactive effects were insignificant. Maximum hydrogen production potential of $1080 \mathrm{ml} \mathrm{H}_{2}$ (L medium) ${ }_{1}^{1}$ was obtained under the optimum condition of glucose concentration $10.18 \mathrm{~g} \mathrm{~L}^{-1}$, yeast extract concentration $2.5 \mathrm{~g} \mathrm{~L} \mathrm{~L}^{-1}$ and $\mathrm{FeSO}_{4} .7 \mathrm{H} 2 \mathrm{O}$ concentration $58 \mathrm{mg} \mathrm{L}^{-1}$. Finally, the RSM was useful to optimize the hydrogen production process and to improve the hydrogen production potential by Clostridium sp. Tr2 isolated from buffalo-dung in Vietnam.

Acknowledgements: The authors gratefully acknowledge the financial support of Vietnam Academy of Science and Technology (Grant No. VAST 05.02/11-12).

\section{REFERENCES}

1. Bisaillon A., Turcot J., Hallenbeck P. C., 2006. The effect of nutrient limitation on hydrogen production by batch cultures of Escherichia coli. Int. J. Hydrogen Energy, 31: 1504-1508.

2. Jo J. H., Lee D. S., Park D., Park J. M, 2008. Statistical optimization of key process variables for enhanced hydrogen production by newly isolated Clostridium tyrobutyricum JM1. Inter. J. Hydrogen energy, 33: 5176-5183.

3. Li Z., Wang H., Tang Z. X., Wang X. F., Bai J. B., 2008. Effects of $\mathrm{pH}$ value and substrate concentration on hydrogen production from the anaerobic fermentation of glucose. Int. J. Hydrogen Energy, 33: 7413-7418.

4. Lin C. Y., Lay C. H., Sen B., Chu C. Y., Kumar G., Chen C. C., Chang J. S., 2012. Fermentative hydrogen production from wastewaters: A review and prognosis. Int. J. Hydrogen Energy, 37: 15632-15642.

5. Lin C. Y., Wu C. C., Hung C. H., 2008. Temperature effects on fermentative hydrogen production from xylose using mixed anaerobic cultures. Int .J. Hydrogen Energy, 33: 43-50.

6. Long C., Cui J., Liu Z., Liu Y., Long M., $\mathrm{Hu}$ Z., 2010. Statistical optimization of fermentative hydrogen production from xylose by newly isolated Enterobacter sp. CN1. Inter. J. Hydrogen Energy, 35: 66576664.

7. Nath K., Das D., 2011. Modeling and 
optimization of fermentative hydrogen production, Bioresour. Technol., 102: 85698581.

8. Pan C. M., Fan Y. T., Xing Y., Hou H. W., Zhang M., 2008. Statistical optimization of process parameters on biohydrogen production from glucose by Clostridium sp. Fanp2. Bioresour. Technol., 99: 3146-3154.
9. Wang J., Wan W., 2009. Experimental design methods for fermentative hydrogen production: A review. Inter. J. Hydrogen Energy, 34: 235-244.

10. Yang H. J., Shen J. Q., 2006. Effect of ferrous iron concentration on anaerobic biohydrogen production from soluble starch. Int. J. Hydrogen Energy, 31: 2137-2146.

\title{
SỬ DƯNG PHƯƠNG PHÁP ĐÁP ỨNG BỀ MẶT ĐỂ TỐI UUU HÓA QUÁ TRİNH SẢN XUẤT HYDRO SINH HỌC CỦA CHỦNG CLOSTRIDIUM SP. TR2 PHÂN LẠPP Ở VIẸTT NAMM
}

\author{
Nguyễn Thị Thu Huyền, Đặng Thị Yến, Nguyễn Thị Yên, Vương Thị Nga, Lại Thúy Hiền \\ Viện Công nghệ sinh học, Viện Khoa học và Công nghệ Việt Nam
}

\section{TÓM TẮT}

Hydro sinh học là nguồn năng lượng sạch, tái tạo và bền vững bởi đây là nguồn năng lượng có nhiệt năng cao nhất và sản phẩm tạo thành khi đốt cháy hydro không gây ô nhiễm môi trường, không ảnh hưởng đến biến đổi khí hậu. Sản xuất hydro sinh học phụ thuộc vào nhiều yếu tố dinh dưỡng và môi trường. Trong bài báo này, chúng tôi xác định điều kiện môi tường tối ưu để nâng cao hiệu suất quá trình sản xuất hydro của chủng vi khuẩn lên men sinh hydro Clostridium sp. Tr2 phân lập từ phân trâu tại Việt Nam. Phương pháp đáp ứng bề mặt được áp dụng để xác định ảnh hưởng qua lại của hàm lượng glucose, cao men và sắt đến quá trình sinh khí hydro của chủng $\operatorname{Tr} 2$ trong điều kiện lên men tĩnh. Kết quả phân tích đáp ứng bề mặt cho thấy khả năng sinh khí hydro của chủng $\operatorname{Tr} 2$ cao nhất trong điều kiện môi trường chứa $10,18 \mathrm{~g} \mathrm{~L}^{-1}$ glucose, $2.5 \mathrm{~g} \mathrm{~L}^{-1}$ cao men và $58 \mathrm{mg} \mathrm{L}^{-1} \mathrm{FeSO}_{4} \cdot 7 \mathrm{H}_{2} \mathrm{O}$. Cả 3 yếu tố này đều ảnh hưởng đáng kể đến khả năng sinh hydro của chủng $\operatorname{Tr} 2$. Sự tương tác qua lại lẫn nhau của 2 cặp yếu tố nồng độ glucose và sắt, nồng độ cao men và sắt phụ thuộc lẫn nhau và ảnh hưởng quan trọng đến khả năng sinh hydro của chủng Tr2. Trong khi đó, cặp tương tác giữa nồng độ glucose và cao men chỉ hơi phụ thuộc nhau và ảnh hưởng tương tác không đáng kể giữa 2 yếu tố này đến khả năng sinh khí hydro của chủng $T r 2$. Trong điều kiện tối ưu, lượng khí hydro lớn nhất thu được sau 22 giờ lên men ở điều kiện kỵ khí tùy tiện đạt $1080 \mathrm{ml}$ hydro/ L môi trường nuôi cấy. Các kết quả thí nghiệm đã chỉ ra rằng phương pháp đáp ứng bề mặt theo kiểu trung tâm đa hợp rất hữu hiệu để tối ưu hóa quá trình sinh khí hydro của chủng Clostridium sp. Tr2 mới được phân lập tại Việt Nam.

Tư khóa: Clostridium, hydro sinh học, lên men, RSM, tối ưu hóa, vi khuẩn, Việt Nam. 